\title{
THE ARCHITECTURAL HERITAGE
}

\section{LAWS: GRAVITY, GROUND, AND RUIN}

\section{Keywords}

Laws

Building

Heritage

Conservation

Essay
Heritage declaration implies a law

protecting buildings from the onslaught

of other laws such as those of physics

or the market. In other words, what the

declaration fights off is obsolescence

- physical or functional - by means of a

legal shield that compels to preserve a

building in a particular state. Analyzing

the debates around the conservation

of the Casa Colorada in Santiago,

this article delves into the inherent

contradictions between the different

laws that affect a building.

The Law of Gravity, the Gravity of the Law

If a builder builds a house for a man and does not make its construction firm, and the house which he has built collapses and causes the death of the owner of the house, that builder shall be put to death.

Hammurabi Code, 1792-1750 B.C. (2005).

[...] as we have always been making mistakes, we will continue to make them in the future. And even if we recognize our mistakes, we will not be able to reconstruct the monuments of the past that we destroyed before.

Adolf Loos, Ornament and Crime (1919).

If we remember the well-known sentence of Adolf Loos, where he defined the architect as the builder who knows Latin, there would not have been much room for legal interpretation at ancient Babylonian time - so loyal to the lex talionis - where, with each mistaken intervention to architectural heritage, those responsible were punished as extremely and irreversibly as the 
damage inflicted on the pre-existence (de Nordenflycht, 2018:346-354).

Fortunately, this is a historical anachronism and, certainly, a disproportion - as modern justice would say -, but it serves as an allegory to get closer to a controversial angle on how the relations between architecture and the laws that regulate its practice have been articulated. If we agree that architectural works are basically subject to two types of laws - some of natural order and others of a cultural order - it would be the architect's job to deal proactively with the former and reactively with the latter. From this point of view, it is interesting to verify how the laws have historically determined, coerced, and even penalized, the practice of those architects who tried to exercise their profession from the confrontation between natural laws and cultural laws.

When it comes to architectural practice, we understand natural laws as those that suppose a physical condition of the used materials so that their formal expression allows to accommodate the needs that the project responds to. Thus, the fact that a part of architectural production could become heritage and that we make the effort to fulfill this voluntary purpose associated with being responsible towards future generations, does not solve all the complexity of two mirroring questions: What are the architectural laws of heritage? And what are the heritage laws of architecture?

We state these questions because if there is an explicit confrontation between internal and external architectural practice laws at a given historical moment, it is precisely when its results set expectations regarding its significance and valuation. In other words, when architecture becomes heritage.

Taking charge of architectural heritage, acknowledging it through interventions on its material reality, could result in an imposition of the collective on the particular interest that a discipline, a trade or a professional practice, freely determines regarding the internal coherence of its own 'agenda,' if this autonomy were possible. Architectural heritage represents many things and, at the same time, is defined specifically by laws that recognize its attributes assigning them certain values, conditions on which a state is established, prohibited or allowed. The state of its conservation.

At a time when the national administration has proposed a modification of the current Law 17,288 of 
National Monuments, dating from 1970, we believe it is pertinent to use the available historical knowledge to review the origin of the doctrines and explain the positions that sustained their deontological foundation, through testimonies collected from different sources between 1969 and 1975 . This allows us to discuss this historical knowledge, where a diagnosis is established between academic, disciplinary and guild actors. Among the latter, the Chamber of Architects expresses:

Many buildings in Santiago have been declared 'national monuments' through very good legal mechanisms [...] Many times due to strange circumstances, that distinction has become a stigma for the building until recently. The Casa Colorada, the Alhambra Palace, the Temple of Santo Domingo, the Pereira Palace, are examples of this statement (Aliaga, 1975:56).

That was said in 1975, making quite clear that in the architecture-heritage conflict, the change of one opposes the permanence of the other. A problem of a sectoral law, amplified in several general laws, of judicialization processes and even of pronouncements from the Comptroller General of the Republic, definitely comes to define and regulate what architecture is, inhibiting a practice that invests its efforts in designing in other ways when facing the possibility of intervening a pre-existence (which in turn can be considered as an opportunity that opens the future, far from wanting to close it). This leads to the cumbersome procedure of intervening a pre-existing building under a large number of imposed limitations that generally depend on value judgments associated with a fraction of the councilors of the National Monuments Council.

Considering the above, to the certainty that the law of gravity must be worked so that the property will not collapse and that its materiality will not easily succumb to obsolescence, in the field of the sectoral laws of cultural heritage, it is added a double meaning of that taxation (insofar the property is levied with duties, to the point that the rights to intervene it without a supplementary control to its national monument status or its inclusion within a typical area are violated). And here is where we find a truly serious problem in the medium term, since these laws generally do not promote innovative responses to the challenge of heritage intervention through project action and architectural design results, on the contrary, they inhibit them.

Consequently, it should come as no surprise that such a conclusion was articulated in favor of defending architecture rather than the monument, developing the foundations of a heritage vision contained in our mirroring questions.

\section{The Ground Law, the Law on the Ground}

In Chile, unfortunately, there is no regard for tradition. 


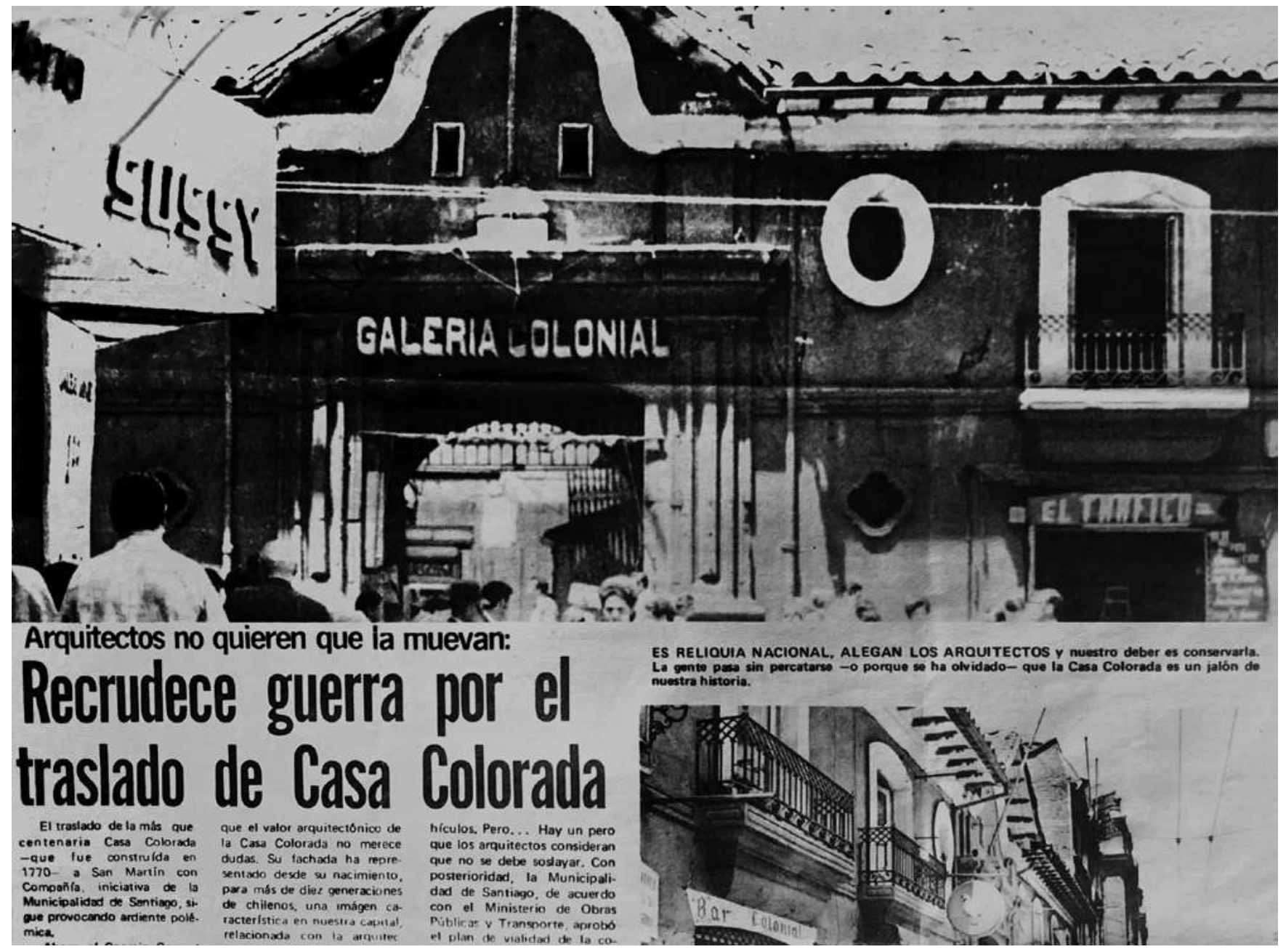

ruins and ramshackle tents [...] We believe that the Historical Commemoration Institute, that has already done so much in this matter, and the official authorities, through competent elements, must do their part to face this abandonment and promptly reconstitute these old monuments that are the symbols of our homeland.

En Viaje (1963).

We all know that our civic responsibility presumes our knowledge of the law, however, the preceding allegation confirms that, many times, the invisibility of the laws occurs even at the institutional level. This, if we consider that the publisher of the magazine En Viaje, which belonged to the State Railways Company, ignored the current Monuments Law ${ }^{1}$ and the role of the National Monuments Council, attributing responsibilities to other non-Governmental institutions, such as the Historical Commemoration Institute. ${ }^{2}$

This observation, that could seem anecdotic and random, is a fragment of a major attempt on the historical reconstruction of the heritage concept in Chile, which necessarily refers us to documentary and monumental sources. We have already raised this
FIG 1. «Recrudece guerra por traslado de Casa Colorada» / "War over the Casa Colorada transfer intensifies". La Tercera de la Hora, 30 de diciembre, 1969. 


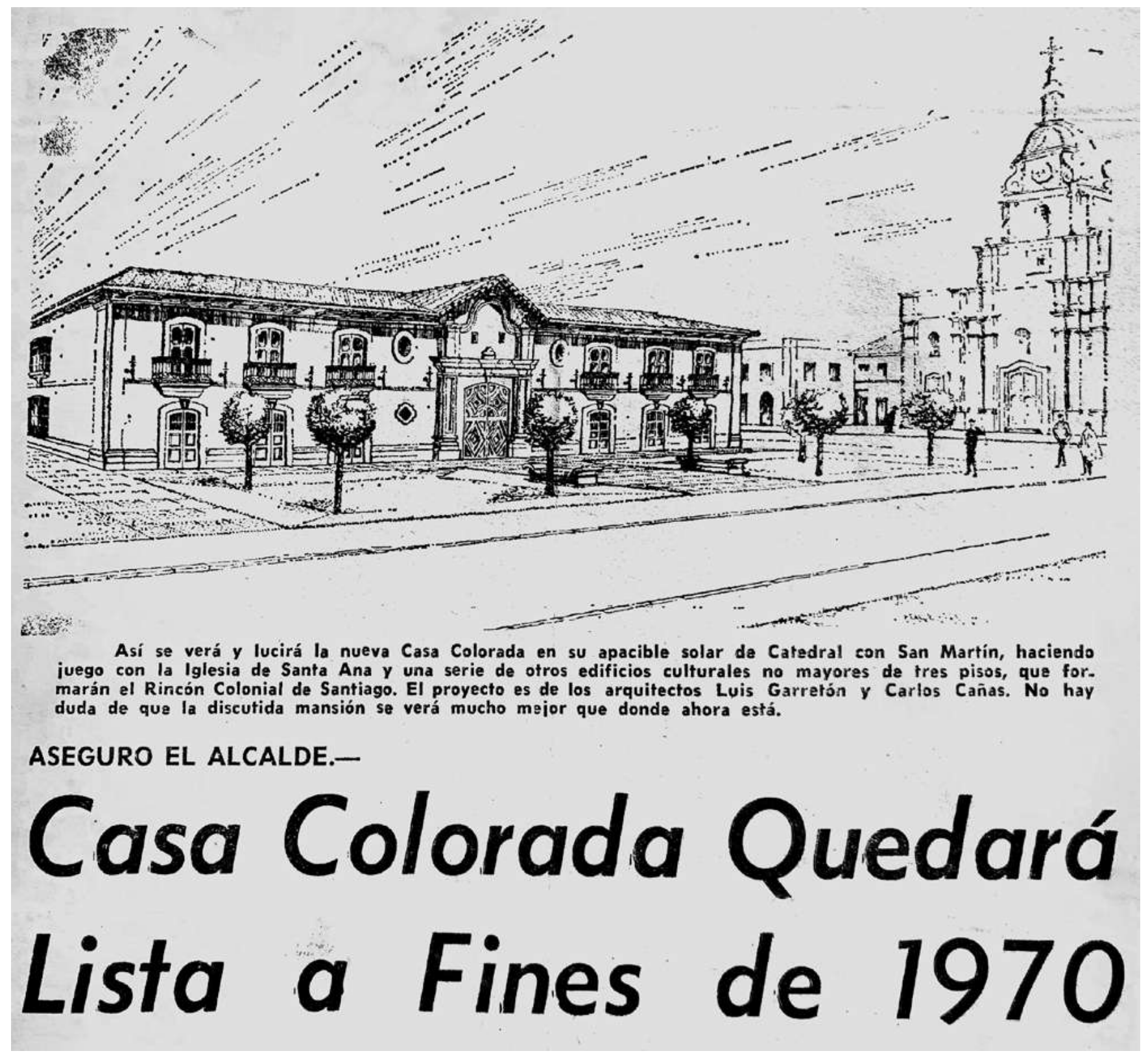

FIG. 2 «Casa Colorada

quedará lista a fines de

1970» / "Casa Colorada

will be ready by the end of

1970". Las Últimas Noticias,

8 diciembre, 1969 . issue when considering the need to understand the phenomenon and establish some disciplinary certainties, concentrating efforts on cases mostly associated with pre-existing architectural production (Nordenflycht, 2019). From the convergence between these documents and monuments, the controversy over Casa Colorada marks a turning point, since this property - located in Santiago's historic downtown -, is iconic regarding the historical values associated with a testimony built at the end of the $18^{\text {th }}$ century in Chile. Basically, a monument in the sense of what is expected of that notion during the first half of the $20^{\text {th }}$ century (FIG. 1).

The conflict over its intervention, announced in 1969 by the Municipality of Santiago, was not installed as a consequence of the value of Casa 
Colorada, founded upon its traditional and historical variables, but by the tolerance to the transformation of those values (mainly architectural). One, in particular, is related to its location, specifically to the availability and the regime of urban land use that considers the conservation of a heritage property according to its original place. Faced with this, the widening of streets and the feasibility of their use as public transport corridors, was a threat to that pre-existing building line. In the words of the architect Héctor Mardones (1969:17):

As part of the preparations to celebrate the Centenary, President Montt, Mr. Pedro, dictates a law called Transformation of Santiago in 1909, which imposes a minimum street width of fifteen meters for the future. The application of this law during sixty years has meant the gradual set-back of the old facades by 2.5 [meters] on each side.

The validation of the Merced Street expansion project meant a section based on the 1960 Law - on the occasion of the celebrations of the 150 years of Independence, proposed by historian Jaime Eyzaguirre - whose collateral damage would be this curious rescue operation which includes disarmament, partial demolition and 'facading,' all with an affectation to authenticity. The objective was to reprogram the use of the property to house the premises of the National Academy of History and the National Academy of Language in a new City Museum. Two institutions belonging to the Institute of Chile that, being direct beneficiaries, never expressed contrary public opinions in this matter. The project of the municipality's Department of Works to move the facade and make three new ones under the design proposed by the architects Luis Garretón and Carlos Cañas, assumed that the so-called 'Colonial Corner of Santiago' would be located in the corners of San Martín and Catedral streets, on the side of the Santa Ana Church, in a site expropriated for this purpose.

The criticisms of this municipal project focused on the fact that the massive reconstruction of the original property would make it a false historical. Several voices agreed that it was a nonsense to disassemble some ornamental elements of the facade and move them to another place to arrange them on a new set of walls. Among those voices, the architect Gonzalo Mardones Restat ${ }^{3}$ stands out, developing an intense union work from the Chamber of Architects of Chile along with his professional work in the TAU group (Silva, 2018), a position he assumed under the presidency of Héctor Valdés after the election of October 1972. ${ }^{4}$ Before that, his public visibility already places him as one of the architects with the strongest drive, accompanied by concrete actions, to defend the Casa Colorada. Mardones served from the Vice Presidency of the Chamber of Architects until his tragic death on November 30, 1974 (FIG. 2,3). 


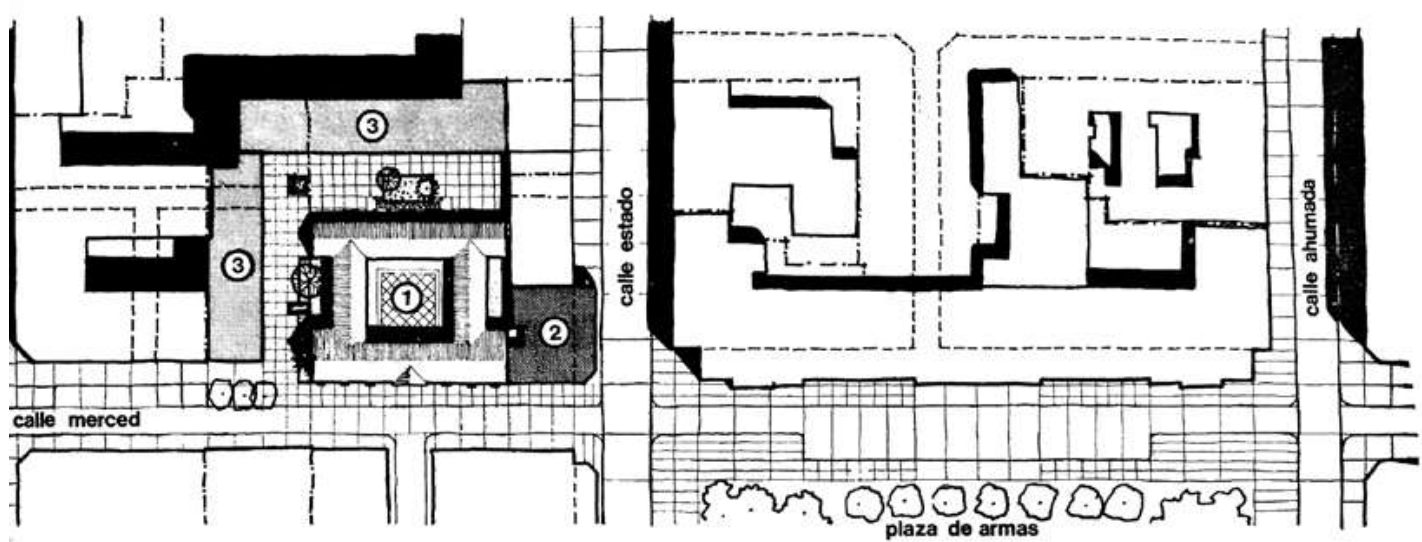

FIG. 3 Gonzalo

Mardones. «Proposición Plano Seccional de Calle Merced entre Plaza de Armas y Miraflores» / "Sectorial plan proposition of Merced street, between Plaza de Armas and

Miraflores". Auca, 17, 1970.
The architect's role is the one that enables the law, its ethics, code of conduct, doctrine or any frame of its collective and individual action, as the president of the order points out in 1969, in light of the conclusions of the forum on the Casa Colorada case:

[...] declares that Chilean cultural history was identified with the systematic destruction of all its heritage, situations where the work of an architect was always present. These statements, said the president, are unacceptable because they seem to blame the architect for a situation whose responsibility primarily concerns the authorities, who have an obligation to ensure the protection of the country's cultural, artistic and historical heritage. [...] It is also inadmissible, he continued, for the authorities to take comfort in the simple fact of having found a presumed guilty or responsible person.

CA 40 (1969):4.

As a result of the disagreement between these positions and after the enactment of the new Law 17,288, the Chamber of Architects persisted in marking a disciplinary position after the push of Gonzalo Mardones and managed to have an ad hoc modification project sent by the president of the order, Héctor Valdés Phillips, on August 2, 1972, to the Executive Vice President of the National Monuments Council, Gilberto Concha Riffo (whose pen name was Juvencio Valle). But it was too late. As we know, the national events unleashed by the opposition to the Unidad Popular Government - which ended with a coup d'état - radically modified the context of a law that from then on would promote its mandate in conditions of liberalization of land use.

\section{The Law of Ruin, the Ruin of the Law}




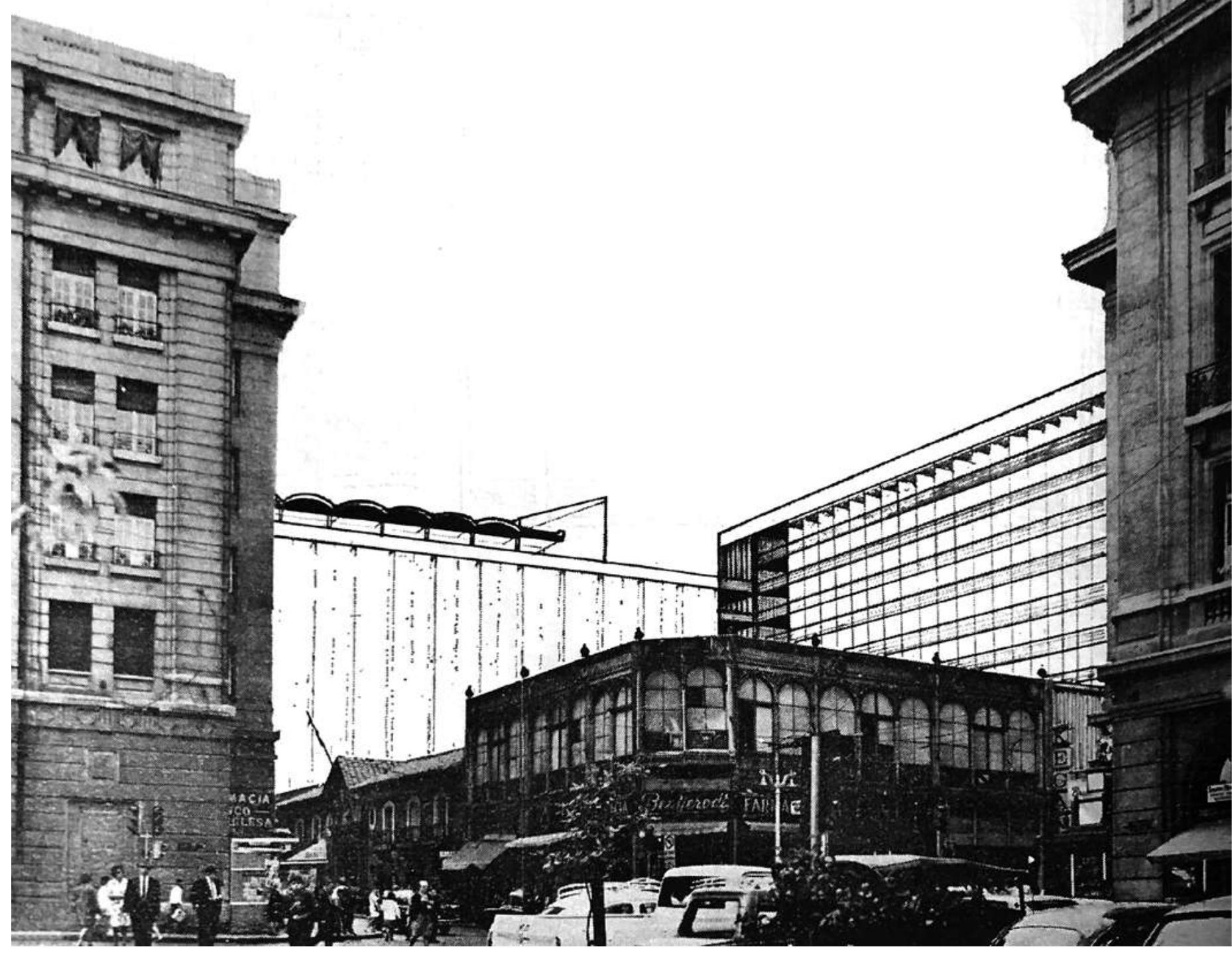

temperaments. It is the most depressing thing the reader can imagine. It would take an etching artist or a poet, perhaps a writer or a journalist, someone capable of describing the indescribable, of painting the horror of a catastrophe.

Héctor Mardones (1969).

The law of ruin is that which assumes architecture as a natural cycle, where the rotting body must be treated with all available prostheses, and where its corpse is sacred. Despite the description, in the same article Héctor Mardones (1969) adds:

Today the house's main nave at street level, which corresponds entirely to its original structure, does not show cracks or possible collapses. Then, it is worth saying that not only reinforced concrete or steel are seismic resistant, and that good masonry and a good gravitational structure design also have seismic resistance conditions.

The conflict over Casa Colorada's fate between the architect Gonzalo Mardones Restat and the mayor of
FIG. 4 Gonzalo

Mardones. «Proposición Plano Seccional de Calle Merced entre Plaza de Armas y Miraflores» / "Sectorial plan proposition of Merced street, between Plaza de Armas and Miraflores". Auca, 17, 1970. 
Santiago, the architect Manuel Fernández Díaz, was followed for months by the written press (FIG. 4,5). The mayor's starting point was to comply with the Law No. 13,936 of 1960, which allowed defining the destination of the property while having its site emptied. The project's purpose was the extension of Merced Street, for which, to overcome the obstacle that Casa Colorada represents, the proposal attempts at the dismantling of its facade in a questionable facadist rescue operation. In addition, the project considered as collateral damage the total and partial demolitions of the Edwards Commercial Building and the Old Courts, now better known as the Pre-Columbian Art Museum. Let's remember that these street-widenings had already wreaked havoc on Santiago's heritage since the early $20^{\text {th }}$ century with the popularly called 'handsaw law' (Law 2,230) of 1909.

The architect Fernando Riquelme was the Director of the Institute of Theory and History of Architecture at the Universidad de Chile, an academic unit that had led the discussion of the contemporary debate on architectural heritage conservation. Under the institute's wing, a Spanish edition of the Venice Charter (1969) is early disseminated, a deontological document that inspires a consensus on intervention criteria, among which the fabric of a building is inseparable from its location, since the condition of place is a heritage attribute. The same document was explicitly considered among the arguments of Gonzalo Mardones (1971:1-5):

The present bill, together with correcting these deficiencies, provides for the conservation of the Casa Colorada on the site that it currently occupies, and that corresponds to the historical place in which important events related to the National Independence took place [...] The technique to be used must correspond to the concepts that the progress of the Science and Art of conservation and restoration has reached, condensed in the Venice Charter of 1964.

The criticism of the National Monuments Council's absenteeism, regarding the control and guidelines of intervention criteria, was total, and even in their declarative function, these were recognized as insufficient and late, since from their origin in 1925, until their end in 1969, they had only declared four buildings in downtown Santiago as National Monuments (San Francisco Church, Palacio de la Moneda, Santo Domingo Church, and Manuel Montt's house).

Moving a work of architecture, an issue that in our imaginary is associated with the house-hauling mingas in Chiloé, is a complex process of registration, cataloging and disarming of the material pieces that make up the original work. A task that, according to mayor Fernández, "was done with the scrupulousness and regard that characterized him, the deceased 
who had worked closely with the Monument Council the previous decades). "Every stone, every wood, every detail, numbered and cataloged so that the reconstitution of the facade and the arch in the new location will be a relatively simple task" (Las Últimas Noticias, 1969). So far everything is reasonable and absolutely legal according to the decree prevailing at the time. However, in his same statement published in Las Ultimas Noticias on December 9, 1969, he adds that: "From its time, the building will retain the spirit, the air, but it will be rebuilt according to the most modern techniques in terms of stability, solidity, hygiene, and comfort for the large public that will visit it daily." Which calls authenticity into question.

This historical episode is an interface of how one legal cycle ends and another begins. The terminal crisis of a law allows to accelerate change, but this was triggered facing an imminent transformation of the national administration, let's recall that the year Law 17,288 began its implementation, coincides with the end of mayor Fernández mandate and the beginning of the Unidad Popular Government.

The laws that regulate the use of land and architecture are a way of projecting on it. In the context of that discussion, the architect Manuel Fernández Díaz (El Mercurio, 1969) states that "what is demolished is in the hands of an architect, and another one will make

FIG. 5 Portada revista $C A$ 14-15, 1975 / Cover of CA Magazine no. 14-15.

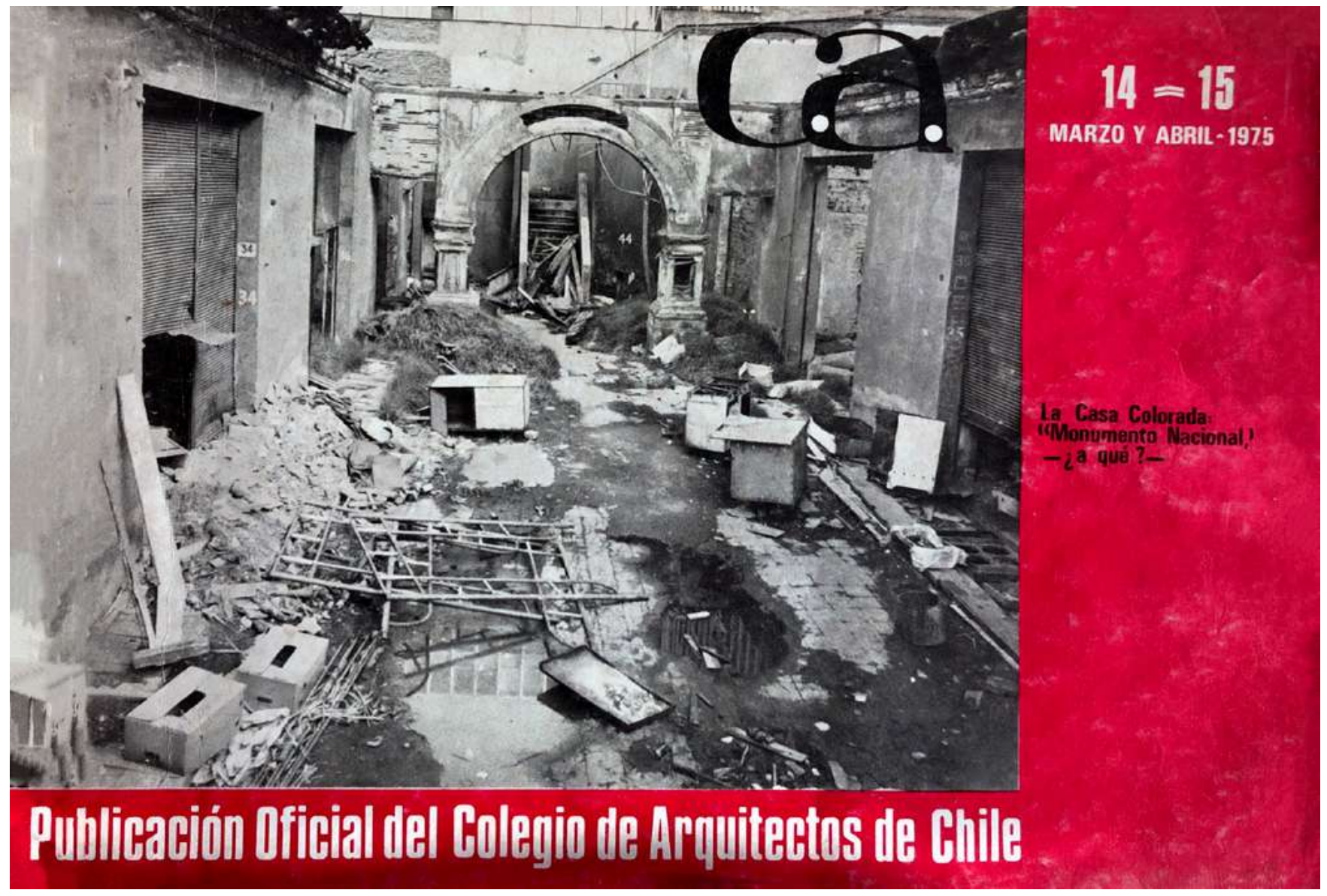


a building there." Eight years after that statement, the Decree-Law No. 1,869 of 1977 abolishes the articles of the previous law and declares the Casa Colorada a Historic Monument. The laws of heritage subject gravity, ground, and ruin to architecture. What one law repeals, becomes the mandate of another.

\section{Learnings for a Conclusion}

As evidenced by this episode of the Casa Colorada, disputes over cultural heritage have not been exempt from trade union and disciplinary controversies, where the cultural image of architecture is identified in the public space as a good whose values are not only the result from the desires of those who design them and take responsibility for their construction.

Half a century from that moment we are again in a situation in which an urgent need to modify the law that governs cultural heritage in Chile has put architecture in a leading place as a cultural practice. A place where 'declarations' and their procedures should focus on the integrity and authenticity of attributes whose variables are conventional, which can be modified without complications according to the convention and the conviction of the moment.

Therefore, public opinion - the informed citizens who demand participation in decisions on the public sphere has been a historical actor in the way in which the need for the valuation of heritage is installed, even mobilizing the modification of a law. As long as this actor is aware of the laws that govern the architectural practice, controversies will be able to refine their arguments, make positions converge and, certainly, build sustainable options tailored to the judgment of future generations, since a heritage intervention always means installing one option over another.

All this is not far from the current moment, where the gravity, the ground and the ruin of a law, things announced for many years now, seem to give way to the opportunity of an accumulated emergency that prompts the laws of architecture to dialogue with those of heritage. ARQ 
1 Decree-Law No. 651 of October 17, 1925, signed by Luis Barros Borgoño and Oscar Fermer.

2 The Chilean Historical Commemoration Institute is a private non-profit corporation founded by the writer Enrique Vergara Robles in 1937, whose mission is to disseminate historical information in the public space through the placement of commemorative plaques. Although the National Monuments Council considers within its members a representative of said private institution, it does not have in its mission to declare - and less to intervene - pre-existing architecture of heritage value.

3 We thank his grandson, the architect Gonzalo Mardones Falcone, for the kindness of giving us access to his grandfather's personal archive, where we found press articles and unpublished documents on the Casa Colorada controversy.

4 Cristian Jara (2015:200) reminds us that "In October 1972, the last elections of the Chamber of Architects were held under Law No. 7,211. There were no elections in the 1972-1982 period. The Military Government suspended union elections of the Chamber of Architects and decided to keep elected councilors in their positions, unless they decided to resign."

José de Nordenflycht Concha

$<$ jnorden@upla.cl>
PhD in Art History from the Universidad de Granada. Associate professor of the Department of Visual Arts at the Universidad de Playa Ancha, adjunct professor at the Escuela de Arquitectura uc and member of the National Academy of Fine Arts of Argentina. Author of the books Patrimonio Local (2004), Post Patrimonio (2012), Patrimonial (2017) and editor of the collective volume Estudios Patrimoniales (2019). This text is part of the Fondecyt Project $\mathrm{n}^{\circ} 3160017$, of which the author is the researcher in charge.

\section{Bibliografía / Bibliography}

AA.vv. Carta Internacional sobre la conservación y restauración de los Monumentos y los Sitios. Venecia 1964. Santiago: Instituto de Historia de la Arquitectura, Facultad de Arquitectura y Urbanismo, Universidad de Chile, r969.

AL1AGA, Carlos. «Agresiones contra Santiago y sus habitantes». CA, I4-I5, (I975), 56 .

BEDRACK, Moisés. «Elaboración de conclusiones sobre la 'Casa Colorada', Intervención de Moisés Bedrack Presidente del Colegio de Arquitectos Sesión del Consejo General del CA n 40-69", I969.

«Casa Colorada quedará lista a fines de I970». Las Últimas Noticias, 9 de diciembre de I969.

DE NORDENFLYCHT, José. «Catecismo patrimonial: convicción, disciplina y traducción». Conversaciones, 5 (20I8): 346-354.

DE NORDENFLYCHT, José (ed.). Estudios patrimoniales. Santiago: Ediciones UC, 2019

JA R A, C. Ciudad, Sociedad y Acción Gremial. Los arquitectos de Chile en el siglo $\mathrm{XX}$, Santiago: LOM Ediciones, 2015.
JOFRÉ, M. «Conservemos nuestras reliquias históricas». En Viaje nº 357, julio I963.

LA RA, Federico (ed.). Código de Hammurabi. Madrid: Tecnos, 2005 [I792-I750 a. C.].

Loos, Adolf. Ornamento y delito y otros escritos. Barcelona: Gustavo Gili, I972.

MARDONES, Gonzalo, CORREA, P. «Proyecto aprobado por el Consejo General en sesión $n^{\circ}$ 22-7I, del 30 de junio de I97I, a proposición de la Comisión del Patrimonio Arquitectónico y Natural». Colegio de Arquitectos de Chile, junio de I97I.

MARDONES, Gonzalo. «Proposición plano seccional de calle Merced entre Plaza de Armas y Miraflores», Auca,I7, I970.

MAR DONES, Héctor. «La casa de piedra colorada». PEC nº 318 (I969), I7. SILVA, Luis. TAU Arquitectos. Santiago: R IL Editores, 2018. «Sin acuerdos terminó Foro sobre la Casa Colorada». El Mercurio, martes 9 de diciembre de 1969 . 